\title{
Front Matter: Volume 7774
}

, "Front Matter: Volume 7774," Proc. SPIE 7774, Linear and Nonlinear Optics of Organic Materials X, 777401 (7 September 2010); doi: 10.1117/12.876875 SPIE. Event: SPIE Photonic Devices + Applications, 2010, San Diego, California, 


\title{
PROCEEDINGS OF SPIE
}

\section{Linear and Nonlinear Optics of Organic Materials $X$}

\author{
Manfred Eich \\ Jean-Michel Nunzi \\ Rachel Jakubiak \\ Theodore G. Goodson III \\ Editors
}

1-2 and 4 August 2010

San Diego, California, United States

Sponsored and Published by

SPIE

Volume 7774

Proceedings of SPIE, 0277-786X, v. 7774 
The papers included in this volume were part of the technical conference cited on the cover and title page. Papers were selected and subject to review by the editors and conference program committee. Some conference presentations may not be available for publication. The papers published in these proceedings reflect the work and thoughts of the authors and are published herein as submitted. The publisher is not responsible for the validity of the information or for any outcomes resulting from reliance thereon.

Please use the following format to cite material from this book:

Author(s), "Title of Paper," in Linear and Nonlinear Optics of Organic Materials X, edited by Manfred Eich, Jean-Michel Nunzi, Rachel Jakubiak, Theodore G. Goodson III, Proceedings of SPIE Vol. 7774 (SPIE, Bellingham, WA, 2010) Article CID Number.

ISSN 0277-786X

ISBN 9780819482709

Published by

SPIE

P.O. Box 10, Bellingham, Washington 98227-0010 USA

Telephone +1 3606763290 (Pacific Time) · Fax +1 3606471445

SPIE.org

Copyright (C) 2010, Society of Photo-Optical Instrumentation Engineers

Copying of material in this book for internal or personal use, or for the internal or personal use of specific clients, beyond the fair use provisions granted by the U.S. Copyright Law is authorized by SPIE subject to payment of copying fees. The Transactional Reporting Service base fee for this volume is $\$ 18.00$ per article (or portion thereof), which should be paid directly to the Copyright Clearance Center (CCC), 222 Rosewood Drive, Danvers, MA 01923. Payment may also be made electronically through CCC Online at copyright.com. Other copying for republication, resale, advertising or promotion, or any form of systematic or multiple reproduction of any material in this book is prohibited except with permission in writing from the publisher. The CCC fee code is 0277-786X/10/\$18.00.

Printed in the United States of America.

Publication of record for individual papers is online in the SPIE Digital Library.

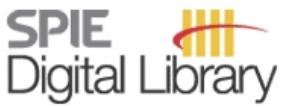

SPIEDigitalLibrary.org

Paper Numbering: Proceedings of SPIE follow an e-First publication model, with papers published first online and then in print and on CD-ROM. Papers are published as they are submitted and meet publication criteria. A unique, consistent, permanent citation identifier (CID) number is assigned to each article at the time of the first publication. Utilization of CIDs allows articles to be fully citable as soon they are published online, and connects the same identifier to all online, print, and electronic versions of the publication. SPIE uses a six-digit CID article numbering system in which:

- The first four digits correspond to the SPIE volume number.

- The last two digits indicate publication order within the volume using a Base 36 numbering system employing both numerals and letters. These two-number sets start with 00, 01, 02, 03, 04, $05,06,07,08,09,0 A, 0 B \ldots 0 Z$, followed by 10-1Z, 20-2Z, etc.

The CID number appears on each page of the manuscript. The complete citation is used on the first page, and an abbreviated version on subsequent pages. Numbers in the index correspond to the last two digits of the six-digit CID number. 


\section{Contents}

vii Conference Committee

\section{NONLINEAR OPTICAL MOLECULES AND POLYMERS}

777403 Analysis of the unusual wavelength dependence of the first hyperpolarizability of porphyrin derivatives [7774-02]

K. De Mey, K. Clays, Katholieke Univ. Leuven (Belgium); M. J. Therien, D. N. Beratan, Duke Univ. (United States); I. Asselberghs, Katholieke Univ. Leuven (Belgium)

777404 Predicting the nonlinear optical response in the resonant region from the linear characterization: a self-consistent theory for the first-, second-, and third-order (non)linear optical response [7774-03]

J. Pérez-Moreno, Katholieke Univ. Leuven (Belgium); K. Clays, Katholieke Univ. Leuven (Belgium) and Washington State Univ. (United States); M. G. Kuzyk, Washington State Univ. (United States)

777408 Electronic responses of donor acceptor substituted twisted biphenyls [7774-07] A. Boeglin, A. Barsella, Institut de Physique et Chimie des Matériaux de Strasbourg, CNRS (France); H. Chaumeil, E. Ay, Lab. de Chimie Organique et Bioorganique, CNRS, Ecole Nationale Supérieure de Chimie de Mulhouse (France); J. Rotzler, M. Mayor, Univ. of Basel (Switzerland); A. Fort, Institut de Physique et Chimie des Matériaux de Strasbourg, CNRS (France)

\section{CHARACTERIZATION}

7774 OB Conjugated polymers: a hyper-Rayleigh scattering study [7774-10] I. Asselberghs, E. Franz, K. Clays, G. Koeckelberghs, T. Verbiest, Katholieke Univ. Leuven (Belgium)

7774 OC Study of two-photon absorption in organic materials by thermal lensing and nonlinear transmission measurements [7774-11]

H. Derbal-Habak, Univ. d'Angers (France) and Institut Matériaux Microélectronique Nanosciences de Provence, CNRS, Univ. Aix-Marseille (France); A. Taouri, Univ. d'Angers (France) and Hassan II Univ. (Morocco); M. Sylla, P. Hudhomme, Univ. d'Angers (France); R. Mountasser, Hassan II Univ. (Morocco); J. M. Nunzi, Queen's Univ. (Canada)

7774 OD Mach-Zehnder interferometry method for decoupling electro-optic and piezoelectric tensor components in poled polymer films [7774-12]

C. Greenlee, A. Guilmo, A. Opadeyi, R. Himmelhuber, R. A. Norwood, M. Fallahi, College of Optical Sciences, The Univ. of Arizona (United States); J. Luo, S. Huang, X.-H. Zhou, A. K.-Y. Jen, Univ. of Wash (United States); N. Peyghambarian, College of Optical Sciences, The Univ. of Arizona (United States) 
7774 OE Size- and concentration-dependent of Rayleigh scattering properties of titanium dioxide nanohybrid polymer [7774-13]

H. I. Elim, B. Cai, O. Sugihara, T. Kaino, T. Adschiri, Tohoku Univ. (Japan)

\section{PROCESSING AND FABRICATION}

7774 OF Theory-guided enhancement of poling efficiency of organic electro-optic materials (Invited Paper) [7774-14]

S. J. Benight, L. E. Johnson, D. B. Knorr, D. H. Bale, I. Kosilkin, B. C. Olbricht, P. A. Sullivan, P. J. Reid, B. H. Robinson, R. M. Overney, A. K.-Y. Jen, Univ. of Washington (United States); W. H. Steier, Univ. of Southern California (United States); S.-K. Kim, H. Fetterman, Univ. of California, Los Angeles (United States); D. W. Prather, Univ. of Delaware (United States);

L. R. Dalton, Univ. of Washington (United States)

7774 Ol Self-organization of organic electronics and photonics materials by microdewetting (Invited Paper) [7774-17]

T. Wachi, H. Kubo, Y. Kiyono, O. Karthaus, Chitose Institute of Science and Technology (Japan)

\section{NANOPHOTONICS AND PHOTONIC CRYSTALS II}

7774 ON Cooperative TPA enhancement via through-space interactions in organic nanodots built from dipolar chromophores (Invited Paper) [7774-22]

A.-C. Robin, V. Parthasarathy, Chimie et Photonique Moléculaires, CNRS, Univ. de Rennes 1 (France); A. Pla-Quintana, Lab. de Chimie de Coordination, CNRS (France); O. Mongin, Chimie et Photonique Moléculaires, CNRS, Univ. de Rennes 1 (France); F. Terenziani, Univ. degli Studi di Parma (Italy); A.-M. Caminade, J.-P. Majoral, Lab. de Chimie de Coordination, CNRS (France); M. Blanchard-Desce, Chimie et Photonique Moléculaires, CNRS, Univ. de Rennes 1 (France)

$777400 \quad$ Multi GHz modulation in ultra compact organic-inorganic structures [7774-23]

M. Eich, J. H. Wülbern, S. Prorok, J. Hampe, A. Petrov, Technische Univ. Hamburg-Harburg (Germany); J. Luo, A. K.-Y. Jen, Univ. of Washington (United States); M. Jenett, A. Jacob, Technische Univ. Hamburg-Harburg (Germany)

\section{DEVICES AND APPLICATIONS}

$7774 \mathrm{OQ} \quad$ Organic electro-optic single crystalline films for integrated optics (Invited Paper) [7774-25] M. Jazbinsek, ETH Zürich (Switzerland) and Rainbow Photonics AG (Switzerland); H. Figi, C. Hunziker, ETH Zürich (Switzerland); B. Ruiz, ETH Zürich (Switzerland) and Rainbow Photonics AG (Switzerland); S.-J. Kwon, O-P. Kwon, Z. Yang, ETH Zürich (Switzerland); P. Günter, ETH Zürich (Switzerland) and Rainbow Photonics AG (Switzerland)

POSTER SESSION

7774 OU Linear and nonlinear optical properties of dendrimer-based nanoclusters [7774-29]

M. R. Parida, C. Vijayan, Indian Institute of Technology Madras (India) 
7774 OV Low threshold laser emissions from dye-doped polymer films in photonic crystal cavity [7774-30]

L.-T. Shi, Technical Institute of Physics and Chemistry (China) and Graduate School of the Chinese Academy of Sciences (China); F. Jin, W.-Q. Chen, Z.-S. Zhao, X.-M. Duan, Technical Institute of Physics and Chemistry (China)

7774 OW Laser induced photoswitching of azobenzene incorporated in PDMS films [7774-31]

S. D. George, V. S. Namboodiri, S. Hardt, Technische Univ. Darmstadt (Germany)

777412 Organic two-dimensional chromophores as media for tunable absorption of entangled photon pairs [7774-39]

A. R. Guzman, M. R. Harpham, O. Suzer, T. G. Goodson III, Univ. of Michigan (United States)

Author Index 
Downloaded From: https://www.spiedigitallibrary.org/conference-proceedings-of-spie on 26 Apr 2023

Terms of Use: https://www.spiedigitallibrary.org/terms-of-use 


\title{
Conference Committee
}

\author{
Symposium Chair
}

Zakya H. Kafafi, National Science Foundation (United States)

Conference Chair

Manfred Eich, Technische Universität Hamburg-Harburg (Germany)

Conference Cochairs

Jean-Michel Nunzi, Queen's University (Canada)

Rachel Jakubiak, Air Force Research Laboratory (United States)

Theodore G. Goodson III, University of Michigan (United States)

Program Committee

Kevin D. Belfield, University of Central Florida (United States)

Antao Chen, University of Washington (United States)

Koen J. Clays, Katholieke Universiteit Leuven (Belgium)

Alain F. Fort, Institut de Physique et Chimie des Matériaux de Strasbourg (France)

François Kajzar, Université d'Angers (France)

Satoshi Kawata, Osaka University (Japan)

Mark G. Kuzyk, Washington State University (United States)

Charles Y. C. Lee, Air Force Office of Scientific Research (United States)

Kwang-Sup Lee, Hannam University (Korea, Republic of)

Geoffrey A. Lindsay, Naval Air Warfare Center Aircraft Division (United States)

Aristides Marcano, Delaware State University (United States)

Robert A. Norwood, College of Optical Sciences, The University of Arizona (United States)

André P. Persoons, Katholieke Universiteit Leuven (Belgium)

Joy E. Rogers-Haley, Air Force Research Laboratory (United States)

Jayan Thomas, College of Optical Sciences, The University of Arizona (United States)

A. Todd Yeates, Air Force Research Laboratory (United States)

Session Chairs

$1 \quad$ Nonlinear Optical Molecules and Polymers

Kenneth D. Singer, Case Western Reserve University (United States) 
2 Characterization

Koen J. Clays, Katholieke Universiteit Leuven (Belgium)

3 Processing and Fabrication

Mireille H. Blanchard-Desce, Université de Rennes 1 (France)

$4 \quad$ Nanophotonics and Photonic Crystals I

Mojca Jazbinsek, Rainbow Photonics AG (Switzerland)

$5 \quad$ Nanophotonics and Photonic Crystals II

Mojca Jazbinsek, Rainbow Photonics AG (Switzerland)

6 Devices and Applications

Manfred Eich, Technische Universität Hamburg-Harburg (Germany) 